\title{
Effectiveness of Skills Teaching Teachers Competence Office Administration Program in State Vocational School 4 Makassar
}

\author{
Sri Wahyuni ${ }^{1}$, Sirajuddin Saleh ${ }^{2}$, Muhammad Darwis ${ }^{3}$ \\ 1,2,3 Universitas Negeri Makassar \\ E-mail: sriwahyunibahtiar@gmail.com
}

(Received: March-2019; revised: May -2019; published: June -2019)

\begin{abstract}
Teacher teaching skills are needed so that teachers can implement and implement various learning strategies in process management so that learning can run effectively and efficiently. This study aim to describe the effectiveness of the application of teacher teaching skills to Office Administration Skills Competencies at SMK Negeri 4 Makassar. This research is a quantitative descriptive study. The population in this study is 317 students, while the number of samples is 47 people. Data collection is through observation, questionnaires, interviews and documentation. Data collected is analyzed through frequency tables and processed through frequency tables and through score calculation techniques to obtain the percentage value of each indicator. The results showed that the effectiveness of the teaching skills of the Office Administration Skills Competency Expertise at Makassar State Vocational High School was in the category of Very Effective in terms of the application of questioning skills, skills of giving reinforcement, variation skills, explaining skills, opening and closing skills, and small group discussion, classroom management skills, and teaching skills of groups and individuals
\end{abstract}

Keywords: Effectiveness, teaching skills, learning

\section{INTRODUCTION}

Education is a necessity for humans as social beings because with human education it will get better. Many things can affect education, one of which is the participation of a teacher or educator (Arhas, 2018; Suprianto, Arhas, \& Salam, 2018). Untuk mengoptimalkan pendidikan yang berkualitas tentunya ada peran seorang guru yang profesional sebagai agen dalam pendidikan formal di lembaga (Avalos, 2011; Borko, 2007; Opfer \& Pedder, 2011).

The main task of a teacher according to the Law on Teachers and Lecturers Article 1 paragraph (1) is to educate, teach, guide, a direct, train, improve and improve students' trainees in early childhood education through formal education, basic education and secondary education. In addition to teaching and transferring knowledge, teachers must also support designs that support the creation of optimal learning processes and outcomes (Ma'ruf, 2015). The skills in designing these various components include the teaching skills of the teacher .

Teachers' teaching skills are needed so that teachers can implement and implement various learning strategies in the management of the learning process that can be run effectively and efficiently. The basic skills of teaching that are applied well will be 
90| Jurnal Administrare: Jurnal Pemikiran Ilmiah dan Pendidikan Administrasi Perkantoran Volume 6 No. 1 January-June 2019. Pages 89-94

followed by processes and good results (Greenhill, 2010; Probert, 2009). Therefore teachers are required to teach skills that learn the learning process. Ideally, teachers who are professional in the learning process are supported by teaching skills, related to the problem, questioning, providing support, expertise in developing variations in learning, explaining and discussing material, encouraging opening and opening learning, encouraging discussion, helping with classroom renewal, and teaching small groups and individuals (Nasrullah, Rumingan, Nasaruddin, \& Niswaty, 2017). Learning in teaching and teaching teaches the teacher will create a learning process that supports and supports students to learn optimally. Teachers who learn to teach have interesting learning techniques so as not to appear in learning, students feel they are not burdened, so learning is needed as a need anymore. Learners will learn without forcing students to learn the benefits of learning itself. Basic teaching skills are very important skills by a teacher. Thus through teaching and learning, it is expected that teachers can optimize the quality of learning.

Teachers who do not have the skills to teach and manage learning will find difficulties and various problems in conveying material or information to students (Amirullah \& Darwis, 2015; Andriana, Tambe, \& Saleh, 2015). Of course, it works on the learning objectives because the learning process is not effective and efficient. The process of transferring material from the teacher to students is hampered because it does not explain explaining, then students will not discuss the material presented. When evaluations and improvements are made to understand students' understanding, participants cannot answer this proving on student achievement. Often students are denied and considered as children who are less intelligent but look from behind the learning process that is not good because the teacher is not gifted with teaching. So that teaching skills do not become obstacles to teachers in transferring their knowledge to students, a teacher needs professional qualifications, one of which is the provision of teaching skills.

\section{METHOD}

This research is a quantitative descriptive. While participation in this study were students in the Office Administration Skills Competency at SMK Negeri 4 Makassar who collected 317 people, while 47 people were selected as the research sample. Data collection through collection techniques, questionnaires, interviews, and collection. Data is collected through frequency tables and processed through frequency tables and through score calculation techniques to obtain percentage values for indicators. 


\section{RESULT AND DISCUSSION}

In this section we will discuss teacher teaching skills from indicators: 1) asking skills 2) strengthening skills; 3) variety preparation skills; 4) explaining skills; 5) open and close learning skills; 6) skills to guide small group discussions; 7) classroom management skills; and 8) group and individual teaching skills. Based on the results of the study, the application of general teacher learning - the average category is very effective with a percentage value> $80 \%$. Although there are two indicators (two) indicators that are still classified as effective categories with a percentage of $72.45 \%$ and $76.94 \%$. Thus, the researchers concluded that the research resulted in the teaching skills of teachers in the Office Administration Skills Competency at SMK 4 Makassar depending on the very effective category with a contribution reaching 82.54 percent. For more details about the indicators of teaching, described as follows:

\section{Questioning Skills}

Questioning skills are the ability of teachers to interact with students with questions that consist of basic questions and follow-up statements. In the results of the research that have been analyzed, the application of teaching skills to the Competency of Office Administration Skills at SMK Negeri 4 Makassar shows results that can be categorized very effectively. The teacher always pays attention to the clarity of the questions, the teacher always provides a reference question, the teacher always focuses on the problem to be asked, the teacher always gives time to think before answering, the teacher always provides guidance to understand the questions, and the teacher often provides tracking questions. Based on the average value of the overall subindicator of asking skills included in the category of very effective.

\section{Strengthening Skills}

The skill of giving reinforcement is the teacher's effort to strengthen and increase the possibility of specific responses from students such as giving rewards consisting of verbal and non-verbal reinforcement. Based on the results of the research that has been analyzed, the application of skills to strengthen teachers' Office Administration Skills Competency at SMK Negeri 4 Makassar shows results that can be categorized effectively. The teacher always gives reinforcement in the form of words, the teacher often says praise to students, the teacher often gives reinforcement with a thumbs up, it's just that the teacher rarely gives reinforcement through touch. Based on the average percentage value of the entire sub-indicator, the application of skills provides reinforcement for teachers, including the effective category.

\section{Skill of Variation}

The ability to attract variations is the ability of teachers to attract attention or variations that attract the attention of students during the learning process consisting of variations in teaching styles, variations in media or teaching materials, and variations in patterns of interaction and activities. Based on the results of the research that has been analyzed, the application of the expertise variations of teachers Office Administration Skills Competency at SMK Negeri 4 Makassar shows results that can be categorized effectively. Responses from 


\author{
92 | Jurnal Administrare: Jurnal Pemikiran Ilmiah dan Pendidikan Administrasi Perkantoran \\ Volume 6 No. 1 January-June 2019. Pages 89-94
}

students about questionnaires number 11 to number 15: Teachers often use variations in sound, teachers often show varied body movements, teachers always change positions when teaching, teachers often use varied media such as the internet, LCD projectors, printed books and others, etc., as well as teachers often use varied teaching patterns.

\title{
Explaining Skills
}

Skills explain the skills related to the ability to communicate with students so that the information/material delivered. Based on the results of the research that has been analyzed, the application of skills that explain the teacher's explanation, the teacher always explains the material systematically and sequentially, the teacher always provides an explanation at the core part of explaining, and the teacher always explains effective or not explain at the end of learning.

\section{Open and Close Learning Skills}

Open and close learning skills, namely the ability of the teacher to begin and end the learning so that students are enthusiastic in learning and at the end of learning the teacher can find out how far the learning was successful or not. Based on the results of the research that has been analyzed, the application of the skills of opening and closing the teacher's learning Competency in Office Administration Skills at SMK Negeri 4 Makassar shows results that can be categorized very effectively. Teachers often attract students' attention at the beginning of learning, teachers often provide motivation at the beginning of learning, teachers always associate the material to be discussed with previous material, teachers always review material at the end of learning, teachers always evaluate learning before closing learning, and teachers always give assignments to students after ending learning.

\section{Skills for Guiding Small Group Discussions}

The skill of guiding small group discussions is the ability of teachers to position themselves as leaders in discussion activities that must teach students to be able to work collaboratively and be compromised. Based on the results of the research that has been analyzed, the application of teacher skills in Office Administration Skills Competency at SMK Negeri 4 Makassar in guiding small group discussions shows results that can be categorized very effectively. The teacher focuses student attention on the material to be discussed, the teacher clarifies the problem or the description of students' opinions so that it is easily understood by other students, the teacher analyzes the students' opinions then the teacher clarifies the students' opinions.

\section{Classroom Management Skills}

The skill of guiding small group discussions is the ability of teachers to position themselves as leaders in discussion activities that must teach students to be able to work collaboratively and be compromised. Based on the results of the research that has been analyzed, the application of teacher skills in Office Administration Skills Competency at SMK 
Negeri 4 Makassar in guiding small group discussions shows results that can be categorized very effectively. The teacher focuses student attention on the material to be discussed, the teacher clarifies the problem or the description of students' opinions so that it is easily understood by other students, the teacher analyzes the students' opinions then the teacher clarifies the students' opinions.

\section{Group and Individual Teaching Skills}

Teaching skills of small groups and individuals is an effort of teachers in responding to differences in students. Based on the results of the research that has been analyzed, the application of small group teaching skills and individual teachers Office Administration Skills Competency at SMK Negeri 4 Makassar shows results that can be categorized very effectively. The teacher always responds to each student as an effort of the teacher's personal approach to students, the teacher always arranges small groups, the teacher always supervises, the teacher always plans learning, and the teacher always closes the discussion.

\section{CONCLUSION}

Based on the analysis and discussion, the research results can be concluded from the eight indicators of teaching skills, teacher teaching skills, Office Administration Skills Competency in SMK Negeri 4 Makassar are included in the category of very effective.

\section{REFERENCES}

Amirullah, A. H., \& Darwis, M. (2015). Kompetensi Kepribadian Guru dalam Meningkatkan Prestasi Belajar Siswa Kelas XII MK Negeri 2 Pinrang. Jurnal Office, 1(2), 148-152.

Andriana, A., Tambe, M. N., \& Saleh, S. (2015). Kompetensi Pedagogik Guru Dalam Melaksanakan Proses Pembelajaran di SMK Negeri 1 Makassar. Jurnal Office, 1(2), 173179.

Arhas, S. H. (2018). Metode Pembelajaran Black Knight. Apa? Mengapa? dan Bagaimana? Jurnal Ad'ministrare, 5(2), 165-172.

Avalos, B. (2011). Teacher professional development in Teaching and Teacher Education over ten years. Teaching and Teacher Education. https://doi.org/10.1016/j.tate.2010.08.007

Borko, H. (2007). Professional Development and Teacher Learning: Mapping the Terrain. Educational Researcher. https://doi.org/10.3102/0013189x033008003

Greenhill, V. (2010). 21st Century Knowledge and Skills In Educator Preparation. In Education.

Ma'ruf, F. (2015). Meningkatkan Hasil Belajar Ips Terpadu Melalui Pemberian Kuis pada Proses Pembelajaran Siswa Smp Negeri 1 Bajeng. Jurnal Office, 1(2), 206-212.

Miles, M. B., Huberman, A. M., \& Saldana, J. (2014). Qualitative data analysis: A method sourcebook. In CA, US: Sage Publications. 
94 | Jurnal Administrare: Jurnal Pemikiran Ilmiah dan Pendidikan Administrasi Perkantoran Volume 6 No. 1 January-June 2019. Pages 89-94

Nasrullah, M., Rumingan, M., Nasaruddin, N., \& Niswaty, R. (2017). Pengaruh Pengambilan Keputusan Kepala Sekolah terhadap Kinerja Guru di SMK Negeri 1 Makassar. Jurnal Ad'ministrare: Jurnal Pemikiran Ilmiah dan Pendidikan Administrasi Perkantoran, 4(2), 103-110.

Opfer, V. D., \& Pedder, D. (2011). Conceptualizing Teacher Professional Learning. Review of Educational Research. https://doi.org/10.3102/0034654311413609

Probert, E. (2009). Information literacy skills: Teacher understandings and practice. Computers and Education. https://doi.org/10.1016/j.compedu.2008.12.018

Suprianto, S., Arhas, S. H., \& Salam, R. (2018). Pengaruh Media Pembelajaran dan Pengelolaan Kelas terhadap Prestasi Belajar Siswa di SMK Negeri Kecamatan Tanete Riattang, Kabupaten Bone. Jurnal Ad'ministrare, 5(2), 137-146. 